\title{
Have Your Texts Been Well-Structured? Mood Block Analysis
}

\author{
Yustika Nur Fajriah, Nurul Wahidah, Rahmat, Ruly \\ Universitas Pendidikan Indonesia \\ Bandung, Indonesia \\ yustikanurfajri@gmail.com
}

\begin{abstract}
This research aims to analyze students' recount texts by using mood block analysis. To achieve this purpose, a qualitative case study design was employed in this study. This study was conducted at one university in Indonesia. The data were collected from six students' recount texts, selected from the category of high, mid, and low achievers. The data were then analyzed inductively. The data analysis includes parsing the texts into clauses, identifying and classifying the mood structure, and interpreting the use of mood structure. The result of this study indicates that the focal students have shown their understanding of positioning Mood elements in making the declarative clauses when telling past experiences. Meanwhile, the students show a lack of understanding of using Finite which functions either to show the polarity or emphasize the degree of information in the text.
\end{abstract}

\section{Keywords: mood block, Mood elements, recount texts}

\section{INTRODUCTION}

Writing is considered not easy to do. It is in line with AlKhasawneh (2010) telling that students still face difficulties in creating good writing. Specifically, it is stated that writing needs so many elements; such as, complex structure, cognitive tasks, and goals, that could be learned by developing the ability to use Lexis and grammar (Hyland, 2004). Furthermore, it is also mentioned that there are some difficulties in writing, and one of them is grammar (Rass, 2015). Besides, the study conducted by Arigusman (2018) shows that many students have still limited knowledge about structures. Simply put, one of the students' barriers in writing is structuring ideas or notions.

Grammar is one of the barriers in writing as mentioned above; there is one element in grammar that must be taken into account; that is, the tenor. Tenor represents the interpersonal metafunction (in Systemic Functional Linguistic theory) in achieving the context of the situation, functioning to show the social relationship between those who take part in a particular situation or communication participants (Halliday, 1985; Martin, 1985). In other words, tenor must be taken into account by teachers in teaching writing.

In line with this, the tenor is realized in the Mood system. As cited in Halliday and Matthiessen (2004), by looking at the mood structure, clause by clause, we can see that the way the dialogue of text proceeds as a series of exchanges (interactive dialogue). Besides, some grammarians such as Halliday
(1994), Eggins (2004), Halliday and Mathiessen (2004), agree that grammatical mood is a grammatical system that has its structure. They see the subject and verb as elements of a clause that realize the structure of mood. Moreover, Schleppegrell (2004) states that mood selection indicates a choice presenting the language use of someone who states, questions, or commands. In each choice, it can give a different relationship between speaker/listener or writer/reader. Therefore, mood block could be applied in structure students ideas in writing.

Relevant studies have been conducted. Some of them focus on the non - academic field (Liping, 2017; Amalia Subandowo, Faliyanti, \& Thresia, 2018; Cordeiro, 2017; Yuyun, 2014; Silva, 2016; Najim, 2008; Fauzi, 2013; Yuliana \& Imperiani, 2017; Dong, 2013; Noor, Ali, Muhabat, \& Kazemian, 2015; Bankole \& Ayoola, 2014; Putri \& Mahdi, 2018). They found that the most dominant Mood used in the non-academic field is declarative, and it is followed by the interrogative and the imperative one. On the other hand, some studies in the academic field (Arigusman, 2018; Silva, 2016) revealed that the clauses are dominated by declarative Mood which shows that the writer put herself as the information provider and the reader is the recipient. Interrogative and imperative clauses were also used indirect speech. However, some of the clauses did not have Mood because of the absence of Subject or Finite or both. This finding is caused by limited knowledge about structures. Another study in the academic field shows that Imperative Mood is the dominant type clause that used. This kind of mood type is used to give someone's command or order.

From the previous studies above, it is found that most of the studies mostly focused on non - academic field. Yet, the studies in the academic field are still necessary to conduct. Therefore, it is still required to do studies in the educational field, as an example in genre. This present study attempts to focus on analyzing students' recount text by using Mood block analysis.

\section{METHOD}

The qualitative case study design was used since this study aims to analyze a particular phenomenon in in-depth analysis; in this case, analyzing students' texts by using a mood block system. This is in line with Creswell (2010) that a case study design reveals the specific phenomena from the participants' point of view. This study was conducted in one of the colleges in Garut with an English education department major. Moreover, the instrument in this study is a collection of texts, precisely six recount texts that were selected with the students' 
levels of writing recount text using the writing rubric in general aspects from Brown (2001). Moreover, those texts were analyzed inductively using the steps from McMillan (1992) and Nunan (1992), including identification, classification, and interpretation. The stages of analysis include parsing the texts into clauses, identifying and classifying the mood structure, and interpreting the use of mood structure (see Eggins, 2004; Gerot \& Wignel, 1994).

\section{FINDINGS AND DISCUSSION}

This section elaborates on the findings of the research focusing on the types of mood structure in students' recount text. Peculiarly, the discussion will be about the elements in Mood; Subject, Finite, Predicator, Complement, and Adjunct. The findings are also connected to the social function, genre move as well as linguistic features of the recount text.

First, Subject. The analysis result shows that from six texts, all of the clauses in that text begin with the Subject. An example of the Subject in students' work is presented below.

A. We help[sic] my grandma's to chop the vegetables.

\begin{tabular}{|l|l|l|l|l|}
\hline We & Help & $\begin{array}{l}\text { my } \\
\text { grandmas }\end{array}$ & $\begin{array}{l}\text { to chop } \\
\text { vegetables }\end{array}$ \\
\hline Subject & Finite & Predicator & Complement & Adjunct \\
\hline MOOD & \multicolumn{2}{|c|}{ RESIDUE } \\
\hline
\end{tabular}

The instance above shows that Subject (we) shows the participant in that clause; as the doer. Additionally, the position of the Subject is appropriate (before Finite) since it is a statement, not the question. Looking at the genre of the text, the use and the position of Subject (declarative mood) have been appropriate. This concept is suitable with personal recount aim; that is, to inform readers regarding past experiences (Knapp \& Watkins, 2005), in which the form of the statement is essential to use (see also Eggins, 2004; Emilia, 2014). This is also confirmed by some previous studies conducted by Cordeiro (2017), Bankole \& Ayoola (2014) that most of the texts begin with a subject in the declarative mood.

Second, Finite. Almost all clauses in the students' texts consist of finite. (See an example below)

\section{B. We arrived at $05.00 \mathrm{pm}$ in the afternoon}

\begin{tabular}{|l|l|l|l|}
\hline We & \multicolumn{2}{|l|}{ Arrived } & $\begin{array}{l}\text { At } 05.00 \mathrm{pm} \text { in } \\
\text { the afternoon }\end{array}$ \\
\hline Subject & Finite & Predicator & Adjunct \\
\hline MOOD & RESIDUE \\
\hline
\end{tabular}

The instance above indicates that Finite was used to show the tense. The position of Finite is also correct; that is, after Subject. This is in keeping with Emilia (2014) that in declarative mood, Finite is placed after Subject. Concerning a linguistic feature of personal recount text; using past tense (Knapp \& Watkins, 2005), is also reflected in the example. The word 'arrived' there indicates that the event happened in the past time. However, there is a student who did not put finite in a clause (ellipsed mood) because of limited knowledge about structures. It can be seen in the following example:

\section{This movie so cute and romance}

\begin{tabular}{|l|l|l|}
\hline This movie & & so cute and romance \\
\hline Subject & Ellipsed finite & Complement \\
\hline Ellipsed MOOD & RESIDUE \\
\hline
\end{tabular}

The finding above shows that the student still had problems in making a simple sentence. This is also contrary to the theory from Eggins (2004) and Emilia (2014) who claimed that Subject and Finite are crucial constituents in a clause Moreover, his result is also different from other previous studies conducted by Arigusman (2018) that most of the analyzed texts on those studies used finite.

The next one is about the position of predicator.

\section{I watch[sic] the movie about love}

\begin{tabular}{|l|l|l|l|l|}
\hline I & \multicolumn{2}{|l|}{ Watch } & the movie & $\begin{array}{l}\text { About } \\
\text { love }\end{array}$ \\
\hline Subject & Finite & Predicator & Complement & Adjunct \\
\hline MOOD & RESIDUE \\
\hline
\end{tabular}

The clause in the table above explains the activity of the participant; that is, watching a movie. It means that Predicator gives content to the verbal element of the proposition, telling listeners what is or was happening. This statement is also supporting the social purpose of recount text (Knapp \& Watkins, 2005; Emilia, 2011) that recount texts shows activities of someone or more in the past time. Subjective orientation is demonstrated by only using a personal pronoun (I and we) and accommodating the absence of reader- the audience is utilized in this step that is categorized as one of the language features of the recount as cited in Schleppegrell (2004). Moreover, it also supports the social function of recount text; to narrate the past event, which does not need supporting pieces of evidence from others since there is no purpose of convincing or persuading readers to do something. However, that example indicates another problem; that is the form of the verb (must be in the past verb). This evidence suggests that the student still had difficulties in Subject and Verb agreement regarding the tense type.

However, Not all clauses need Predicator. The below example shows that nominal phrases are also required to be used in telling activities; such as saying conditions, describing people or particular places. It means that the absence of a Predicator, it is accepted.

\section{E. The air around the waterfall is very cool.}

\begin{tabular}{|l|l|l|}
\hline $\begin{array}{l}\text { The air around the } \\
\text { waterfall }\end{array}$ & Is & Very cool \\
\hline Subject & Finite & Complement \\
\hline MOOD & RESIDUE \\
\hline
\end{tabular}

However, the tense (a form of being) is a similar problem with the previous example. The word 'is' is not suitable since 
the condition of the event is in the past, not now. Therefore, the nominal clause of the simple past had not fully understood by the student.

Another element is the Complement. Theoretically, Complement is beneficial to develop the clauses. It is relevant to Eggins and Slade (1997) and Emilia (2014) that interpersonally complement is used to expand the field of negotiation. Complement can be in some categories of a word; noun, adjective, or adverb.

\begin{tabular}{|l|l|l|l|l|l|}
\hline $\begin{array}{l}\text { One } \\
\text { year } \\
\text { ago } \\
\text { and I } \\
\text { friend }\end{array}$ & \multicolumn{2}{|l|}{$\begin{array}{l}\text { Went } \\
\text { Camping }\end{array}$} & $\begin{array}{l}\text { on the } \\
\text { mountain } \\
\text { of } \\
\text { papanday } \\
\text { an }\end{array}$ \\
\hline $\begin{array}{l}\text { Adjun } \\
\text { ct }\end{array}$ & $\begin{array}{l}\text { Subje } \\
\text { ct }\end{array}$ & $\begin{array}{l}\text { Finit } \\
\mathrm{e}\end{array}$ & $\begin{array}{l}\text { Predicat } \\
\text { or }\end{array}$ & $\begin{array}{l}\text { Complem } \\
\text { ent }\end{array}$ & Adjunct \\
\hline & MOOD & \multicolumn{5}{|c|}{ RESIDUE } \\
\hline
\end{tabular}

The example reflects that complement is very useful in completing the meaning of an expression in a clause. This is relevant to the previous study conducted by Yuliana and Imperiani, (2017) and Noor et al. (2015) that complement used in the texts to complete the meaning of a clause

The last element to discuss is adjunct; mood adjunct and conjunctive adjunct. As an example, 'I was very tired, but I was happy'. The use of mood adjunct (very) is an intensification type to show someone's attitude. As mentioned by Eggins (2004), the expression of intensification adds the interpersonal meaning of the text as seen from I was very tired but I was happy that the writer expresses his happiness in spite of his fatigue towards his traveling to his uncle's home. Of course, it is also in keeping with Gerot and Wignel (1994) that in the reorientation step, the writer involves personal opinion/ evaluation of events occurred. Conjunctive adjunct is also crucial in making recount texts. This type of adjunct is very needed to use in recount text since chronological order functions to help readers understand the events that happened in the version. Correctly, the words (then, after that) are also used in this part which supports the criteria of this schematic structure; sequencing the events (Gerot \& Wignel, 1994; Emilia, 2014). One of the clauses are presented as follows:

\begin{tabular}{|l|l|l|l|l|l|}
\hline Then, & I & \multicolumn{2}{|l|}{ Bought } & $\begin{array}{l}\text { A bottle } \\
\text { of water }\end{array}$ & $\begin{array}{l}\text { Across the } \\
\text { wicketkee } \\
\text { per }\end{array}$ \\
\hline $\begin{array}{l}\text { Adjun } \\
\text { ct }\end{array}$ & $\begin{array}{l}\text { Subje } \\
\text { ct }\end{array}$ & $\begin{array}{l}\text { Fini } \\
\text { te }\end{array}$ & $\begin{array}{l}\text { Predicat } \\
\text { or }\end{array}$ & $\begin{array}{l}\text { Complem } \\
\text { ent }\end{array}$ & Adjunct \\
\hline \multicolumn{5}{|c|}{ MOOD } & \multicolumn{3}{l}{ RESIDUE } \\
\cline { 2 - 4 }
\end{tabular}

The example above realized that adjunct is necessary for sequencing the events and realizing adverb. This is in line with Silva (2016) and Najim (2008) that adjunct used in the texts to sequence the event and realize adverb.
As the summary, below is the Table I of the analysis result of the Mood Structure of the text.

TABLE I. THE ANALYSIS RESULT OF THE MOOD STRUCTURE

\begin{tabular}{|l|c|c|c|c|l|}
\hline & $R(\%)$ & Sig. F & $\begin{array}{c}\text { Mean } \\
\text { Square }\end{array}$ & $\boldsymbol{t}$. & $P$-Value \\
\hline Trained Vocalist Musical Score & 42 & $0.009 *$ & 0.15 & 2.36 & $0.03 *$ \\
\hline $\begin{array}{l}\text { Trained Vocalist Phonological } \\
\text { Score }\end{array}$ & 15 & 0.143 & 0.23 & 0.75 & 0.14 \\
\hline $\begin{array}{l}\text { Trained Vocalist Musical Score } \\
\text { and Phonological Score }\end{array}$ & 52 & $0.002 *$ & 1.85 & 3.74 & $0.002 *$ \\
\hline Untrained Vocalist Musical Score & 38 & $0.013 *$ & 0.34 & 2.52 & $0.025^{*}$ \\
\hline $\begin{array}{l}\text { Untrained Vocalist Phonological } \\
\text { Score }\end{array}$ & 39 & $0.012 *$ & 0.34 & 2.36 & $0.034^{*}$ \\
\hline $\begin{array}{l}\text { Untrained Vocalist Musical Score } \\
\text { and Phonological Score }\end{array}$ & 64 & $0.0002 *$ & 4.36 & 5.43 & $0.0001 *$ \\
\hline
\end{tabular}

Note:

$$
\begin{aligned}
\square & =\text { Completed } \\
\mathrm{X} & =\text { Uncompleted } \\
* & =\text { It is still accepted, although not all clauses have it. }
\end{aligned}
$$

From the table above, it can be concluded that most of the students have understood to involve the elements of Mood in a clause structure; the Subject, Finite, Predicator, Complement, and Adjunct. This result contributes to fulfilling the social function, text organization as well as linguistic features of the personal recount text. Nevertheless, some problems are found, such as the appropriateness of tenses and the absence of finite. It means that some of the students still have barriers in showing the tense of a statement and the importance of the verb as the main element after the Subject in making a clause.

\section{CONCLUSION}

This study concludes that students have been understood to structure a declarative Mood in the recount texts through the correct position of Subject, Finite, and Predicator. Nevertheless, there is still inadequacy in which there are some texts which lack Finite; therefore, the clarity of time, as well as degree and polarity of the information, is low. Moreover, the tense marking (the verb form) is also one of the matters in this analysis result. Hence, it is suggested for English teachers to teach Mood elements explicitly; both the structure and the position of each element); therefore, the meaning of the written texts could be maximally conveyed interpersonally. Corrective feedback is also suggested to be involved in teaching students' writing.

\section{REFERENCES}

Al-Khasawneh, F. M. S. (2010). Writing for academic purposes: Problems faced by Arab postgraduate students of the college of business, UUM. ESP World, 9(2), 1-23.

Amalia, M., Subandowo, D., Faliyanti, E. F., \& Thresia, F. T. (2018). An analysis of domain mood and modality. English Language Teaching Educational Journal (ELTEJ), 1(1), 22-28. doi: 10.12928/eltej.v1i1.144

Arigusman, A. (2018). An analysis of student"s narrative text writing: An SFL. International Journal of Languages, Literature, and Linguistics, 4(2), 93 100. doi: 10.18178/ijll1.2018.4.2.156 
Bankole, M. A., \& Ayoola, M. O. (2014). Mood and modality in christian magazines: A systemic functional analysis of christian women mirror. International Journal of Humanities and Social Science, 4(14), 138-149.

Brown, D. (2001). Teaching by principles: An interactive approach to language pedagogy. New York: Longman

Cordeiro, C. M. (2017). Using systemic functional linguistics metafunction as a tool in identifying agency in organizational change in cross-cultural management contexts. International Journal of Cross-Cultural Management, 17(1), 125-135. doi: 10.1177/1470595817694914

Creswell, J. W. (2010). Research design: Pendekatan kualitatif, kuantitatif, dan mixed. Yogyakarta: PT Pustaka Pelajar.

Dong, J. (2013). Interpersonal metaphor in legal discourse: Modality in crossexaminations. Journal of Language Teaching and Research, 4(6), 13111321. doi: 10.4304/j1tr.4.6.1311-1321

Eggins, S. (2004). An introduction to systemic functional linguistics. New York: Continuum International.

Eggins, S., \& Slade, D. (1997). Analysing casual conversation. London: Cassell.

Emilia, E. (2011). Pendekatan genre-based dalam pengajaran bahasa inggris: Petunjuk bagi guru. Bandung: Rizqi Press.

Emilia, E. (2014). Introducing functional grammar. Bandung: Pustaka Jaya.

Fauzi, S. (2013). Mood and speech function realization of rights and responsibilities in "twitter's terms of service" (Unpublished bachelor's thesis). Universitas Dian Nuswantoro.

Gerot, L. \& Wignel, P. (1994). Making sense of functional grammar: An introductory workbook. Sydney: Antipodean Educational Enterprises.

Halliday, M. A. K. (1985). An introduction to functional grammar. London: Edward Arnold.

Halliday, M. (1994). An introduction to functional grammar. China: Foreign Language Teaching and Research press.

Halliday, M., \& Matthiessen, M. (2004). Introduction to functional grammar. London: Arnold.

Hyland, K. (2004). Genre and second language writing. Ann Arbor: University of Michigan Press.
Knapp, P., \& Watkins, M. (2005). Genre, text, and grammar. Sydney: UNSW Press Book.

Liping, C. (2017). Mood, modality and polarity analysis of Winston S. Churchill's speech on Hitler's invasion of the U.S.S.R. Advances in Social Sciences Research Journal, 4(1), 195-202. doi: 10.14738/assrj.41.2625

Martin, J. R. (1985). Factual writing: Exploring and challenging social reality. Melbourne: Deakin University Press.

McMillan, J. (1992). Educational research: Fundamentals for the costumer. New York: Harper Collins Publisher.

Najim, H. (2008). A Systemic approach to the study of the clause as exchange in imperative and exclamative clauses in English and Arabic. Buhuth Mustaqbaliya Scientific Periodical Journal, 4(1), 7-34.

Noor, M., Ali, M., Muhabat, F., \& Kazemian, B. (2015). Systemic functional linguistics mood analysis of the last address of the holy prophet (PBUH). International Journal of Language and Linguistics, 4(1), 1-9. doi: 10.11648/j.ij1l.s.2016040101.11

Nunan, D. (1992). Research methods in language learning. United States of America: Cambridge University Press.

Putri, G. J., \& Mahdi, S. (2018). Mood analysis of financial services taglines: A systemic functional linguistic. UI Proceedings on Social Science and Humanities, 2(1), 1-4.

Rass, R. (2015). Challenges face Arab students in writing well-developed paragraphs in English. English Language Teaching, 8(10), 49-59. doi: 10.5539/elt.v8n10p49

Schleppegrell, M. J. (2004). The language of schooling: A functional linguistics perspective. London: Lawrence Erlbaum Associates Publisher.

Silva, T. C. (2016). Mood and modality in audiovisual research articles. Rev. Ens. Educ. Cienc. Human, 17(1), 72-79.

Yuliana, D., \& Imperiani, E. (2017). The realization of interpersonal meaning in course newsletter: A systemic functional linguistic perspective. Indonesian Journal of Applied Linguistics, 7(1), 181-188. doi: 10.17509/ijal.v7i1.6873

Yuyun, I. (2014). A study of assertiveness in a debate setting. Indonesian Journal of Applied Linguistics, 3(2), 140-153. doi: 10.17509/ijal.v3i2.27 